\title{
Coastline dynamics of the northern Lower Casamance (Senegal) and southern Gambia littoral from 1968 to 2017
}

Thior, M., Sané, T., Dièye, E.H.B., Sy, O., Cissokho, D., Ba, B.D., Descroix, L.

Journal of African Earth Sciences, Accepted 26 August 2019

https://doi.org/10.1016/i.jafrearsci.2019.103611

\begin{abstract}
Northern Lower Casamance and southern Gambia's beaches, just like those of West Africa, are subject to significant morpho-sedimentary dynamics characterized by coastline mobility. Such mobility, combined with significant variations in different places, is characterized by some globally erosive trend (-1.2 to 6m/year, in sandy areas extending from Senegal to Sierra Leone and -1 to $-15 \mathrm{~m} /$ year from Ivory Coast to Nigeria). The purpose of this article is to analyze the coastline evolution in Lower Casamance and southern Gambia based on a diachronic survey (1968-2017). The reference line used to demonstrate the variation of the coastline is the vegetation boundary.

The results obtained are based on the digital processing of geospatial data (aerial photographs, Landsat and Google Earth images).

The different variations of the coastline are obtained through the calculation of two indexes considered as the most relevant ones. The first one, the End Point Rate (EPR) index, helped measure the difference between two successive coastlines and the second one, the Linear Regression Rate (LRR) index, allows assessing the ability to estimate the evolution of each segment over the entire period considered. These mobility indexes (EPR and LRR) show some variable dynamics of the coastline, featured by two trends: the first one, under accretion in the 1968-1986 period and the other one, globally erosive during 1986 - 2017 period.
\end{abstract}

Keywords: coastal evolution, coastlines erosion, risk mapping, geospatial techniques, Lower Casamance, Gambia.

\section{Introduction}

West African shorelines have been evolving at an accelerated rate in recent decades (Pennober, 1999). Sadio (2017) reported rates of retreat, ranging from -0.49 to $-14.21 \mathrm{~m} / \mathrm{yr}$, with an average of $-3.55 \mathrm{~m} / \mathrm{yr}$ in the median segment of the Sangomar spit. The same author noted also an accretion varying between +1.58 to $+5.31 \mathrm{~m} /$ year; the average rate being $+2.81 \mathrm{~m} /$ year south of the distal segment. In addition, Abé (2005) described shoreline dynamics with a 
retreat of $1.27 \mathrm{~m}$ / year in Port-Bouët Bay which evolves in conditions of relative stability. This mobility, highly variable in location, is characterized by a globally erosive trend in the Gulf of Guinea and West Africa. In fact, 70\% of the world's coasts are threatened by erosion (Bird, 1985). This trend has been accentuated with a mean sea-level rise of $3 \mathrm{~mm}$ since the beginning of the 21st century. Paskoff (2001) argued that ongoing global warming, as documented by instrumental data, is expected to continue due to the additional anthropogenic greenhouse effect with impacts on coastal evolution. Global warming will thus speed up the rise of the sea level and will increase storms frequency and intensity. This is likely to be followed by an acceleration of coastal erosion process and an extension of temporary or permanent flooding of low coastal areas (Roques et al., 2010, Bird, 1985). In general, coastal areas with unconsolidated and very low sediment features tend to erode faster than those with a consolidated composition (Stefan et al., 2017).

In Senegal, particularly in the "Langue de Barbarie", a very densely inhabited sand spit bounding the Senegal River delta in the Saint-Louis region, the coastline retreat is occurring at a rate of $-4.32 \mathrm{~m}$ / year (Sy, 2013, Sadio, 2017, Ndour et al., 2018) and -2 to -7m in Gorée Island (Bakhoum et al., 2017). According to (Faye 2010, Thior, 2019), shoreline erosion is intensive in Casamance coast, particularly in Diogué, Carabane, Gnikine, Diembéring, Kafountine, Abéné and Niafrang areas. This situation is influenced by dominantly long and regular swells (Sadio, 2017, Thior et al., 2019a). In this area, sedimentary dynamics is determined by natural factors and human interventions. The swells and waves, generated by winds and currents, are among the most important forces influencing and determining the coastline dynamics. Our study area is influenced by two types of swells. The first one, the Northwest swell is oblique to the Senegalese coast and is drifting from north to south throughout the year (Faye 2010; Sadio 2017, Thior et al., 2019b). Its oblique direction from north to south causes, on the southern coasts, the formation of coastal spits and sandy ridges extended towards the south. These spits and ridges are visible on the Gambian and Casamance coasts, particularly at Karton Point (Gambia), Diogué, Kalissaye and south of the mouth of the Casamance River. The second swells; the Southwestern swell is more conspicuous during the rainy season (June to September), with an extensive dispersal of sediment towards the coast (Pennober 1999). Its influence is especially noticeable throughout the north direction of sand dunes on the Casamance and Gambian coasts. This explains the slight North-oriented spits of the left riverbanks of the small streams of the Casamance River (Kalissaye, Salindia, and Ebedou). 
Therefore, the morpho-sedimentary parameters are largely based on the influence of these two dynamic agents.

The retreat of the coastline is partly due to erosion and remains a major concern in coastal areas. Most of the population and economic activities are concentrated on West African coastal areas (Faye, 2010). The importance of these activities makes these areas attractive but also very complex (Maanan et al., 2018). In fact, these West African littoral environments are intensively urbanized and highly coveted due to the numerous economic activities (fishing, tourism, industrial activities, trade and services). However, these highly coveted environments are often facing problems related to global changes such as the coastline retreat. This retreat, linked to coastal erosion, causes lot of damage, hinder economic activities and sustainable development especially in urban coastal areas (Martinez et al., 2018,). Consequently, beach erosion and coastal cliff retreat have become major problems along many of the world's sandy coasts (El Mrini et al., 2012; Federico et al., 2018).

Because of the socio-economic and ecological importance of the West African coastline, it is therefore necessary to reflect on the evolution of the coastline in order to prevent coastal risks in a context of climate change marked mainly by the sea level rise.

The consequences of the retreat of the coastline remain significant both for the environments and the socioeconomic activities in the coastline of northern Lower Casamance and southern Gambia, focus of this study.

This part of Senegambia coast, which is moderately man-made, is characterized by a rural coastal population. The population consists mainly of fishermen in Gambia and rice farmers in Casamance. There are touristic facilities also in this area in addition to fishery processing centers owned by Chinese businessmen. On one hand, these socio-economic facilities cause flooding and coastal erosion risks, and on the other hand are decisive factors in the disturbance of the coastal system. The study area, located in West Africa and bordered by the Atlantic Ocean, the coastline of northern Lower Casamance and southern Gambia (figure.1) belongs to the South-Sudanian tropical climate domain with maritime influence. It is a part of the SenegalMauritanian sedimentary basin which confers particular geomorphological characteristics in this coastline expressed by a relative strong littoral dynamics. 


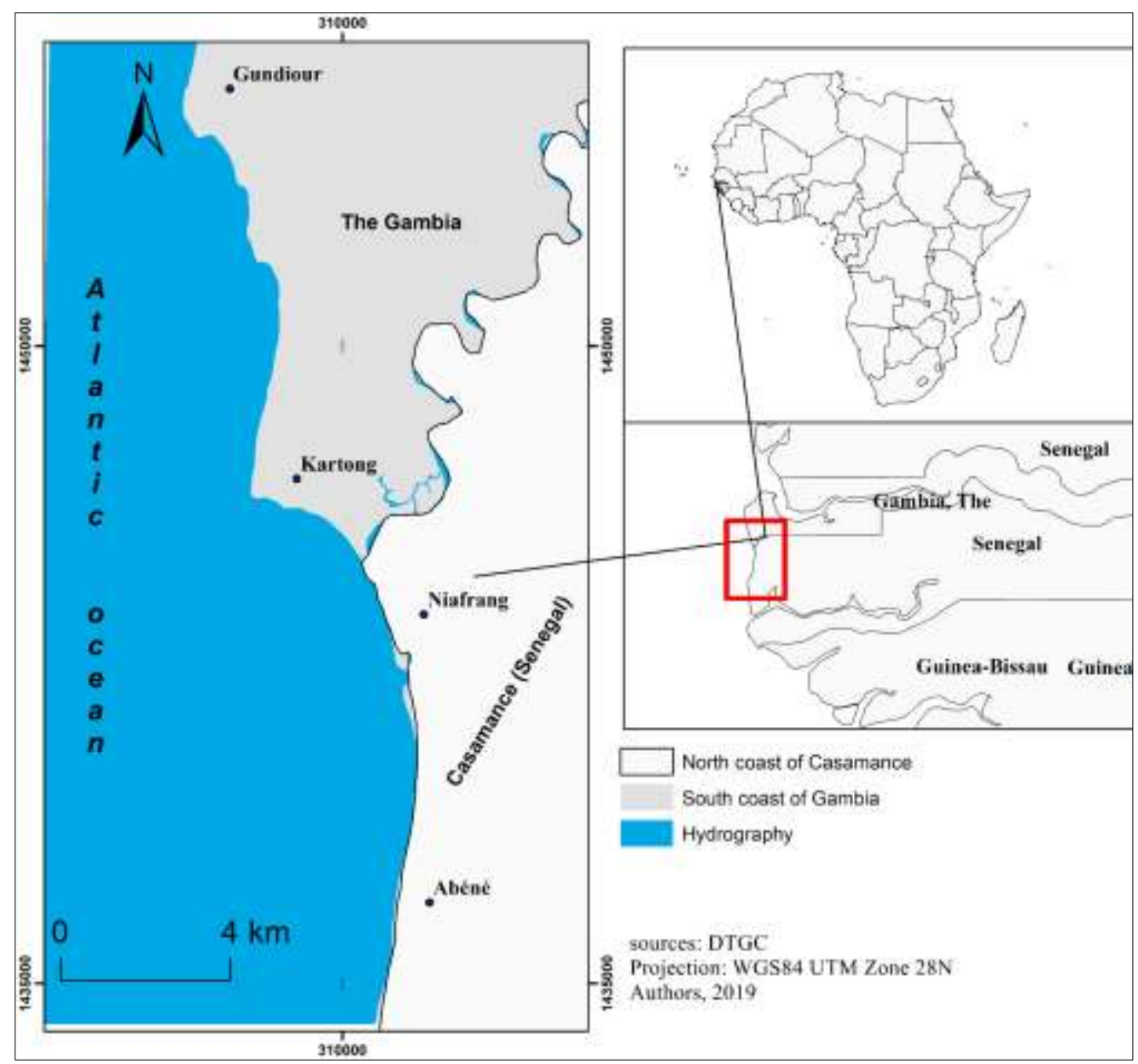

Figure1: Location of the study area in Senegal and the Gambia

\section{Materials and methods}

The methodology is based on a superposition of multi-date images from different sources. These are aerial photographs acquired in 1968 by France National Geographic Institute (IGN), archived and made available through CSE library, 1986 Landsat images collected from archives provided by Landsat Data Continuity Missions instruments and downloaded free via the http://glovis.usgs.gov/site, and Google Earth images which cover the years 2004 and 2017 (tab.1). The analysis was performed on the basis of computer-assisted interpretation. The method is based on the choice of a coastal reference line, the geometric correction of geospatial data, the digitization of the coastline, the estimation of margins of uncertainty and the calculation of the rate of evolution of the coastline... 
Table 1: Geospatial Data Used

\begin{tabular}{|l|l|l|l|l|l|}
\hline Data & Missions & Acquisition date & Sensor/focal & $\begin{array}{l}\text { Resolution } \\
\text { / scale }\end{array}$ & Sources \\
\hline $\begin{array}{l}\text { Aerial } \\
\text { Photography }\end{array}$ & $\begin{array}{l}\text { ND 28 } \\
\text { II-III }\end{array}$ & $01 / 01 / 1968$ & $\begin{array}{l}15 \text { UAGI 1041 - } \\
151,869\end{array}$ & $\begin{array}{l}1 \mathrm{~m} \\
1 / 40000\end{array}$ & CSE Senegal \\
\hline Landsat & $\begin{array}{l}\text { Series } \\
\text { L5 }\end{array}$ & $02 / 09 / 1986$ & Sensor TM & $30 \mathrm{~m}$ & Earth Explorer \\
\hline $\begin{array}{l}\text { Google } \\
\text { Earth }\end{array}$ & -------- & $07 / 03 / 2004$ & & $0.90 \mathrm{~m}$ & Google Earth \\
\hline $\begin{array}{l}\text { Google } \\
\text { Earth }\end{array}$ & --------- & $03 / 12 / 2017$ & ------------------- & $0.90 \mathrm{~m}$ & Google Earth \\
\hline
\end{tabular}

\subsection{The choice of a coastline indicator}

The difference in image quality means that known reference lines do not appear with the same intensity levels. In the existing literature, there are more than a dozen reference lines as pointed out by Boak et al., 2005 and Faye et al., 2013. The quality of the image then appears as a determining parameter in the detection of a reference line.

The spatial resolution is $1 \mathrm{~m}$ on aerial photographs and the limit of vegetation is clearly visible. On the other hand, images resolution is $30 \mathrm{~m}$ for the Landsat data acquired in 1986. However, the limit of the vegetation at the beach front, whether dune (Vegetation line, seaward edge of dune vegetation) or perennial (Line of permanent, stable, long-term vegetation) is visible through results of a color composites operation. The application of preliminary process operations of the 1986 satellite images is based on the ENVI 4.2 software. Thus, from visible to infrared, several images are provided by the TM sensor. We must therefore adopt an approach which places targeted information in the field at the core. Given that the vegetation is essential here for the extraction of its limit, the red channel of the electromagnetic spectrum remains adequate for the treatment, especially as it highlights the contact between the dry sediments of the backshore and vegetation cover (Robin et al., 2016; Le Berre et al., 2016). Then, a thresholding allowed identifying, thanks to a net limit (reference line), the pixels representing the terrestrial area (clear pixels) and the marine domain.

On Google Earth images, some of the oldest of which go back to 2004, the spatial resolution is depending on the zoom factor. Indeed, $1 \mathrm{~m}$ resolution allows to reliably detect every type of reference line in different places. Moreover, the smaller the area to download, the higher the resolution will be. Thus, as part of this analysis, several images were downloaded and then 
mosaicked through the ArcGIS map interface. Once the georeferencing is appropriate, the images already mosaicked are projected into a WGS84, UTM, Zone $28 \mathrm{~N}$ coordinate system.

\subsection{Geometric correction (Georeferencing)}

Compared to selected aerial photographs, the Google Earth raw images do not show any real geometric distortions. As the different images are orthorectified, and the verification of the georeferencing appropriate in the same geodesic projection WGS84 UTM 28N, the error margins obtained were not greater than $1 \mathrm{~m}$. Indeed, during these operations and to reduce potential margins of errors, we made sure that the first image on each site, in this case the most recent, is well rectified; all other images being subsequently wedged on it. This method led to a better understanding of the error margins and to gradually reduce them.

In addition, it should be noted that among several existing methods of geometric image correction, the one adopted here relies on the combination of coordinates collected in the field using a GPS and those from the Google Earth platform.

\subsection{Digitization of the coastline}

As the images are orthorectified, and the georeferencing appropriate, the digitization of the coastline was carried out through ArcGIS 10.5 software. The DSAS 4.3 extension for ArcGIS was used to calculate the shoreline change rate. The calculation of the shoreline evolution trend requires the prior establishment of at least two digitized-coastlines at different dates. The pillars of the DSAS extension involve measuring differences between the coastlines of a same series and to compute the statistics of the evolution rates (in $\mathrm{m} /$ year). This requires prior rigorous data formatting in a customized geodatabase, the establishment of a baseline and equidistant transects, an estimation of the uncertainty related to the method as well as the choice of indexes relating to the coastline evolution (Crowell et al., 1994, Faye et al., 2013). When all the input parameters are filled, the DSAS automatically generates the transects depending on the chosen measurement step. The transects perpendicular to the coast are used to measure the differences between the shorelines. Based on this, the average erosion rates are determined on each transect. From then, we will be able to create a geodatabase designed as an environment to foster the statistical computation. This includes creating two entities: a first entity containing one or more reference lines named baseline and a second entity carrying coastlines already digitized on ArcMap named shorelines. These entities are included in a buffer (buffer shoreline) which stabilizes the linear space in which the coastlines were digitized.

\subsection{Estimation of margins of uncertainty}

The accuracy of coastline analysis results is very often influenced by several sources of error, especially when the coastline position is historical (Crowell et al., 1994, Moore 2000; Esmail 
et al., 2019). The quality of a diachronic analysis results is thus closely linked to the knowledge of the margin of error. Indeed, the error margins can define the state of the coastline (erosion, stability, accretion) over a specific period. The estimation of these risks of errors must lead to the development of a margin of error, which will be taken into account in the interpretation of the results (Durand, 2000). For this reason, the most common errors in coastline kinematics, especially for coastline analysis, are mainly positioning errors and technical ones.

In the literature, the global error called Global Position Error of the Coastline is calculated by using the square root of the sum of the errors squared (Fletcher et al., 2003; Nassar et al., 2018, Moussaid et al., 2015, Dada et al., 2019 ). In this study, the value of the three errors already identified in the images has been calculated for each year. This gives the following formula for each date:

$$
\begin{gathered}
\text { Ope }=\sqrt{P e^{2}+G e^{2}+D e^{2}} \\
\boldsymbol{E} \boldsymbol{\alpha}=\frac{\sqrt{O p e 1^{2}+O p e 2^{2}}}{\text { Period }}
\end{gathered}
$$

Ope: Overall position error of coastline;

Pe: Pixel error;

Ge: Georeferencing error (RMS) ;

Ed: Digitizing error (multi-entry);

E $\alpha$ : Error on average.

The sum of these square roots gives the error of a studied time step. To integrate the margin of error on the analysis results, the sum of the sums of the global position errors of the coastline must be obtained for each time step analysis (table 1).

Table 2: Calculation of Periodic Error Margins on Coastline Positioning in Kartong-Abéné sector

\begin{tabular}{|l|l|l|l|l|}
\hline Date/Error & $\mathbf{1 9 6 8}$ & $\mathbf{1 9 8 6}$ & $\mathbf{2 0 0 4}$ & $\mathbf{2 0 1 7}$ \\
\hline Pixel error & 1 & 30 & 0.5 & 0.5 \\
\hline Ortho correction error (RMS) & 0.045 & 0.2 & 0.29 & 0.32 \\
\hline Digitizing error (multi-entry) & 0.035 & 1.33 & 0.17 & 0.23 \\
\hline Overall position error of coastline & 1 & 30.03 & 0.6 & 0.63 \\
\hline Time period & $1968-1986$ & $1986-2004$ & $2004-2017$ & \\
\hline
\end{tabular}




\begin{tabular}{|l|l|l|l|l|}
\hline $\begin{array}{l}\text { Overall error on average in } \mathbf{m} / \\
\text { year }\end{array}$ & 1,66 & 1.66 & 0,06 & \\
\hline Error on the period in $\mathbf{m}$ & 30.04 & 30.03 & 0.87 & \\
\hline
\end{tabular}

\subsection{Calculation of the shoreline evolution rate}

The outcomes are reported under two headings. The first one represents the difference between two dates (two coastlines) and the second one takes into account all the coastlines (1968, 1986, 2004 and 2017). At first, the evolution rate calculation indices need to be determined.

The End Point Rate (EPR) calculates the ratio of the distance between the coastline corresponding to the earliest and most recent date. Thus, when only two shorelines are available, the EPR remains a good index for evaluating kinematics (Moore, 2000, Thieler et al., 2005, Himmelstoss, 2009; Tahri et al., 2017). This explains is why it is used to evaluate the variations between 1968-1986, 1986-2004 and 2004-2017.

The Linear Regression Rate (LRR) is the index used to estimate the evolution of each segment over the entire period considered (1968, 1986, 2004 and 2017). The number of individuals in the statistical series is the number of coastlines. If this number is low as for the EPR, this raises the problem of the relevance and the robustness of the results. Thus, calculating the annual rate of change of the reference lines along each transect, the LRR is therefore more relevant when analyzing the coastal kinematics of more than two dates. Indeed, the calculation method takes into account the evolutionary distance of the coastline over the entire period considered (Nassar et al., 2017; Faye et al., 2013). Moreover, the graphical representation is determined by the statistical results of the calculated indices. It visually visually shows the evolutions measured in several forms of graphs. Thus, depending on the indices, two types of graphical representations are used in this study. The first representation is based on the classification of transects on ArcGIS, allowing to see the evolution rate between two coastlines. The second graphic is in the form of an area. Thus, on the ordinate axis we have the longitudinal axis of the linear extent of the range and, on the abscissa axis, the evolution of the coastline.

\section{Results of the kinematics of the coastline}

\section{1-The coastline evolution between 1968 and 1986}

The studied segment includes the south of The Gambia and goes as far as Abéné north of the coast of Casamance. It is a segment length of $40 \mathrm{~km}$ characterized by a relatively turbulent coast. As a result, between 1968 and 1986 erosion and accretion occur in some places. The map analysis highlighted three areas of evolution. The northern segment, although highly contrasted by erosion and accumulation, presents a negative balance of its evolution (Figure 2). 


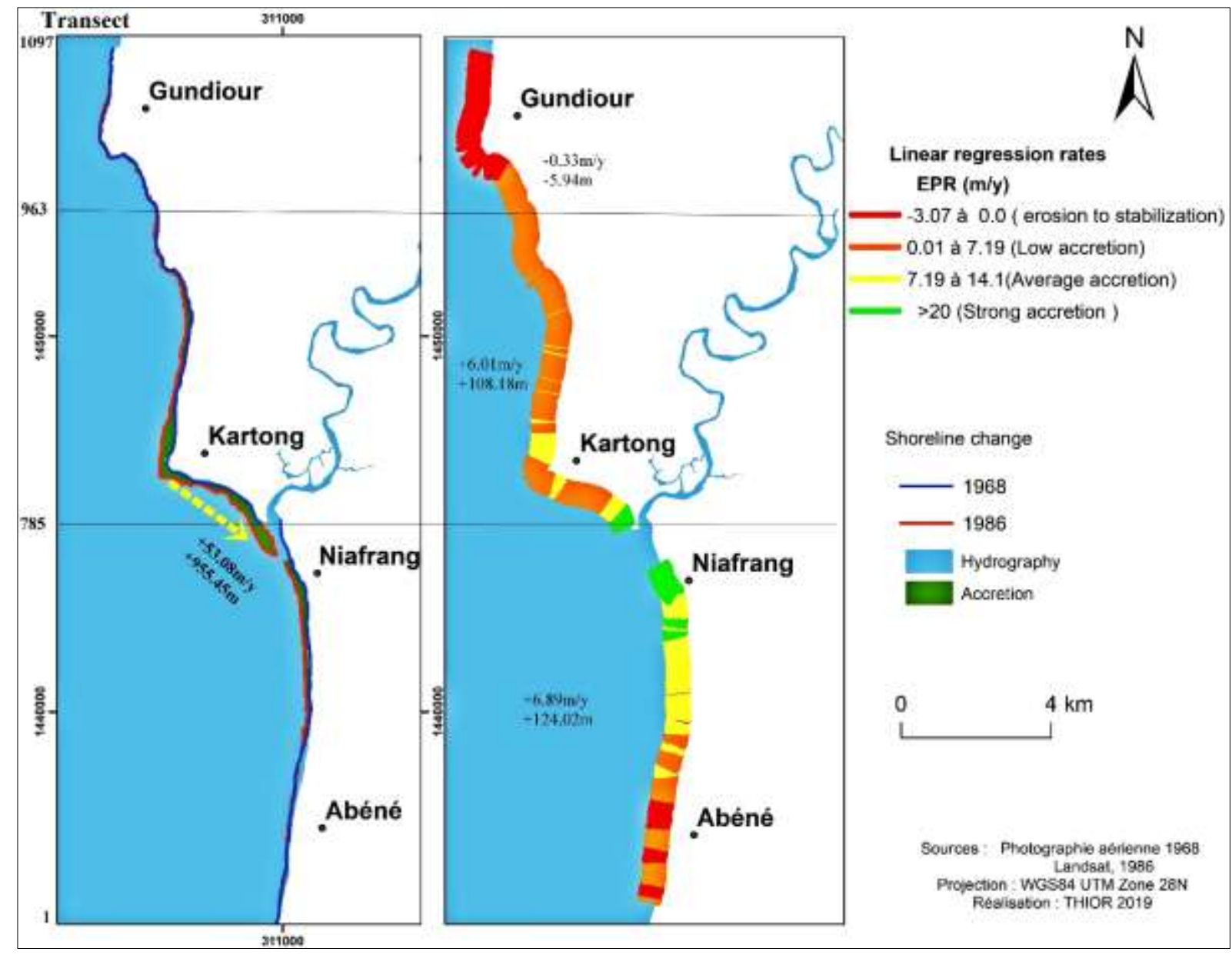

Figure 2: The coastline evolution and statistical representation between 1968 and 1986

For this purpose, an annual average erosion rate of $-0.33 \mathrm{~m}$ is observed. But this rate of retreat is between the margin of error which is $1.66 \mathrm{~m} /$ year and, therefore, it is difficult to interpret this rate. On the other hand, in the center of the sector, we observe a reverse situation with an average accretion of $+6,01 \mathrm{~m} /$ year. South of the segment, the rate of change increased slightly, an accumulation of $+6.89 \mathrm{~m} /$ year. Furthermore, in 18 years, the tip of the spit has prograded + 955.45m with a north-south orientation in accordance with the longshore sediment transport towards the south, an average increase of $53.08 \mathrm{~m} /$ year (figure 2).

\subsection{Evolution of the coastline between 1986 and 2004}

Unlike the 1968-1986 period, characterized by shoreline development and generally manifested by accretion, that of 1986-2004 shows a very active erosion on the whole sector with an uncertainty of $1.66 \mathrm{~m}$. The north of the sector has the lowest coastline evolution rate, averaging $-4.76 \mathrm{~m} /$ year. As for the center, it records the highest evolution rate of the sector with $-7.24 \mathrm{~m}$ / year. The coastline evolution rate decreases in the south with an average erosion of $-4.57 \mathrm{~m}$ / year (figure 3). 


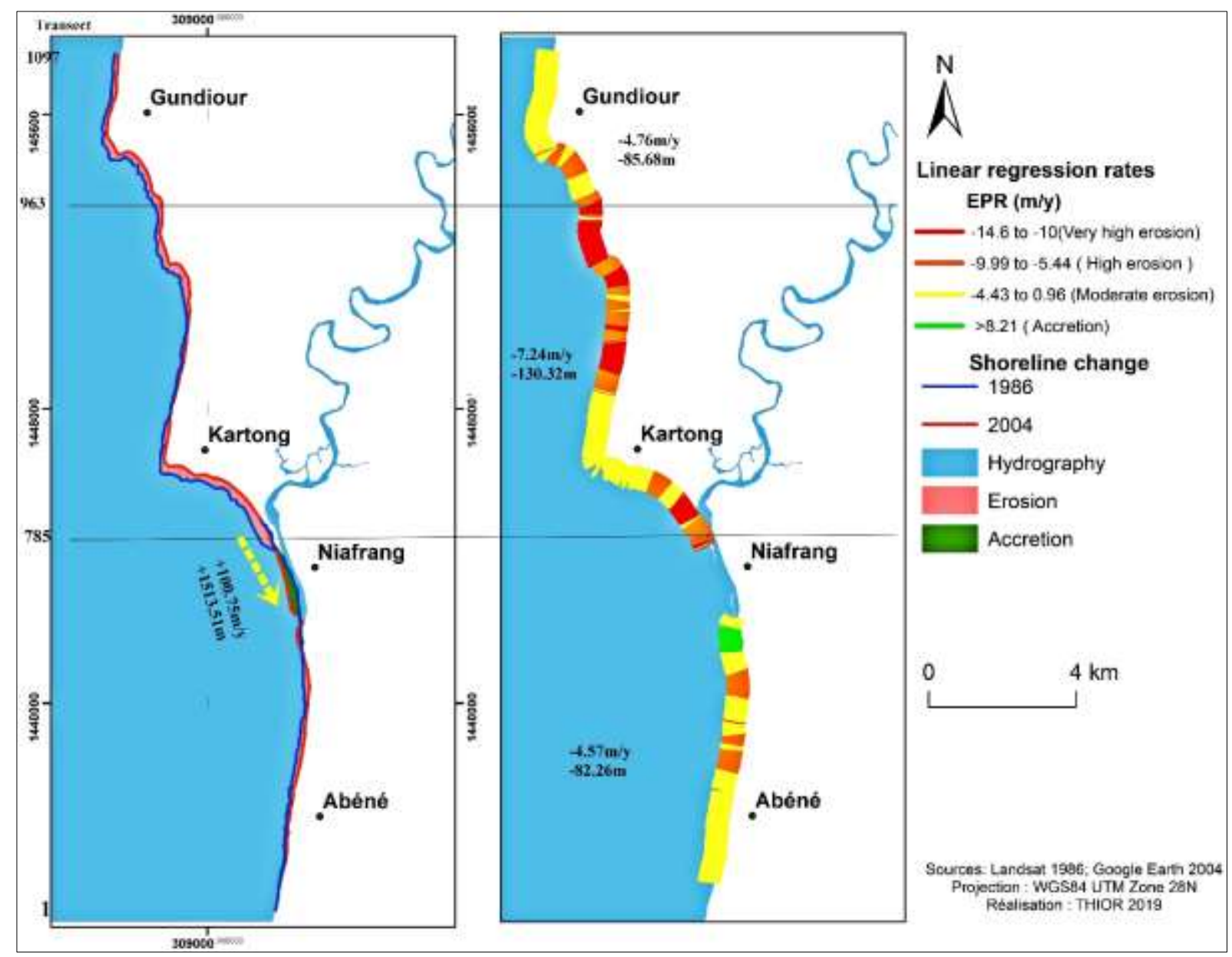

Figure 3: Coastline evolution and statistical representation between 1986 and 2004

On the other hand, the spit narrows and continues accelerating its progression towards the south under the effect of the longshore drift. Thus, the tip of the spit has increased by $1813.51 \mathrm{~m}$ over a period of 18 years (1986/2004), an average increase of $+100.75 \mathrm{~m} /$ year (figure 3 ).

\subsection{Evolution of the coastline between 2004 and 2017}

The period 2004-2017 is a period during which erosion has continued to manifest itself across the sector because the rates of change far exceed the margins of uncertainty, albeit at a slower pace. Thus, it can be seen in the north of the sector a rate of retreat of $-1.39 \mathrm{~m} /$ year. This remains relatively low compared to the center of the sector where erosion is more pronounced with an annual average erosion of $-3,75 \mathrm{~m} /$ year. In the South South of the sector, the erosion rate is less significant than in the center, averaging $-2.03 \mathrm{~m} /$ year. However, the spit has remained relatively stable for 13 years, particularly between 2004 and 2017 (Figure 4). 


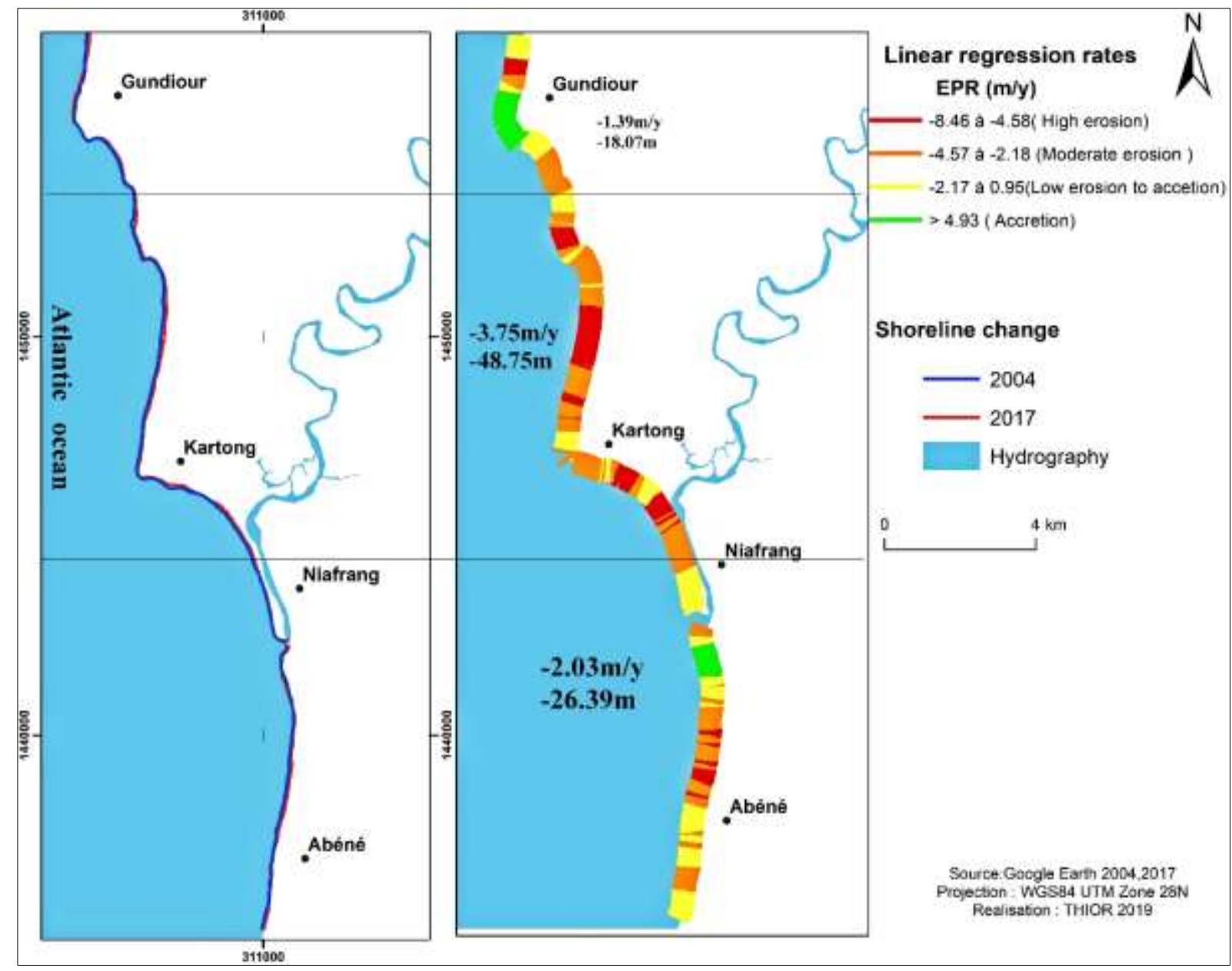

Figure 4: The coastline evolution and statistical representation between 2004 and 2017

The analysis shows a contrasting evolution across the sector between 1968 and 2017, in a span of 49 years. Indeed, the analysis of this coastline evolution is based on the EPR index which makes it possible to calculate the rate of evolution on only two dates. It is therefore necessary to calculate the coastline evolution trend over the entire period considered. However, this trend is achieved through the calculation of the LRR index. This is why the map of the coastline evolution illustrates the changing trends between 1968 and 2017, while considering intermediate dates, notably 1986 and 2004 (figure.5).

\subsection{Synthesis of the average evolution of the coastline between 1968, 1986, 2004, 2017}

In general, there appears to be a contrasting evolution periods of accretion and erosion in the studied areas.

That is why, on the southern beaches up to transect 328 , the trend is erosive with an average retreat rate of $-1.28 \mathrm{~m} /$ year, yielding an erosive balance of $-62.72 \mathrm{~m}$. Between Kartong Point and the Niafrang Spit, the trend is gradual with a accretion of $203.35 \mathrm{~m}$, an average evolution rate of $+4.15 \mathrm{~m} /$ year (figure.5). 
This part of the sector, particularly between transects 328 and 785, corresponds to a deposition zone, since it is the area of progression of the sandy spit On the other hand, the north part, marked by a progradation, shows an erosion which naturally fertilizes the spit. Characterized by a small bay, this part between transects 785 and 963 has indeed been eroded by $-154.35 \mathrm{~m}$, an average erosion rate of $-3.15 \mathrm{~m} /$ year. The extreme north of the sector is almost in sedimentary stability with still an average evolution of $+0,012 \mathrm{~m} /$ year for the whole period.

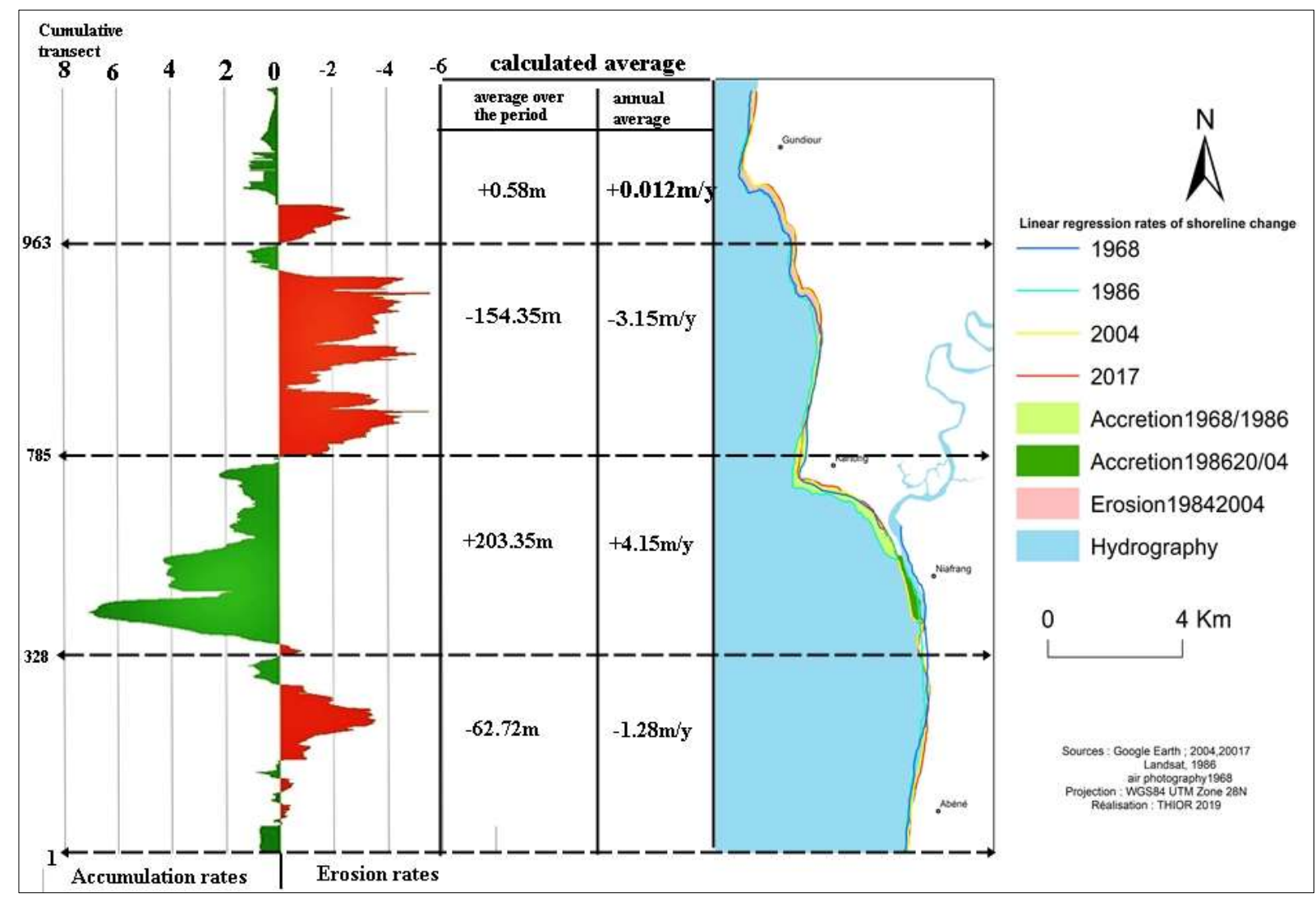

Figure 5: Synthesis and graphical representation of the coastline evolution from 1968 to 2017

\section{Discussion}

The purpose of this study is to analyze the coastline mobility. The results obtained are relatively interesting. The application of the DSAS statistical calculation model in this approach on the coastline between northern Casamance and southern Gambia required obtaining multi-date geospatial data. The results of the superposition of these data are questionable because of the margins of error related to the resolution of the Landsat images $(30 \mathrm{~m})$, the seizure of the coastline, the georeferencing (RMS) that must be considered in the analysis. However, the use of correction techniques for these errors has yielded acceptable results. The approaches which depend primarily on the type of coast (rocky / sandy, microtidal / macrotidal, mobile / fixed, vegetated or not, etc.), allow the choice of one or several reference lines. This results in the 
diversity of media and extraction techniques on which the margin of error depends upon (Bakhoum et al., 2017, Nassar et al., 2018, Moussaid et al., 2015, Dada et al., 2019; Durand 2000, Byrnes 1994, Crowell et al., 1993. In this study the limit of the vegetation is used as a reference line. Remember that our study area is little anthropized. Therefore the vegetation is very natural. However caution should be used when using the vegetation line as an indicator of the coastline, in areas where human practices can significantly alter the position of the coastline (Gould et al., 2015, Gibbs et al., 2015). Despite the limitations of the computer-aided photointerpretation methodology, the results on rates of change on the studied coastline are comparable to the work of the authors who had to work on the issue at the scale in West Africa. Our results on progradation rates at the Kartong point confirm those of Faye (2010), but with a difference in the values of accumulation or retreat. Indeed, between 1979 and 1986, the peak progressed towards the south by a rate of $+142.09 \mathrm{~m} /$ year (Faye, 2010) while our results show an increase of $+54.08 \mathrm{~m} /$ year. This difference is certainly related to spatial scales of analysis that are not the same. In addition, the evolution of the tip of Kartong is recent because the sand spit did not exist in 1968. Indeed, Sadio (2017) reported, the hydrodynamic operation of the mouth of the Gambia which allows a sedimentary exchange between its internal and its external. This can always be justified by the fact that the genetic relatedness between the sand particles of the samples taken in the estuary and the outer coast are noted. These results are broadly in agreement with our observations on sedimentary dynamics. Naturally, on the SenegaleseGambian coast, swell is an essential element in remodeling beaches. By tearing sand material that will be suspended offshore, the swell induces a longshore drift which mobilizes the sands towards the south. Some of these particles are locally deposited (Kartong Point) and the rest drifted south. Thus, between 1986 and 2000, the results of our work are also practically similar with a slight difference related to the monitoring interval. According to Faye (2010), this represents a growth rate of $+110.30 \mathrm{~m} /$ year in 14 years, whereas this growth rate is $100.75 \mathrm{~m} /$ year in 18 years (1986 and 2004). Note that these measures relate only to the Kartong spit.

Moreover, compared to the results of (Sadio, 2017), the trends in both cases remain more or less similar even though the time scales are longer in our study. However, Sadio measurements based on a purely remote sensing approach did not specify the margins of error.

The approach adapted in this study is globally based on spatial analysis techniques. These overlapping techniques for mapping and statistics to calculate coastline evolution rates have limitations in this study. They can be of a technical nature with possible errors related to the superposition of geospatial data of different nature and quality. In addition, there is a lack of quantification of sediment balance, which is not the subject of our study. 


\section{Conclusion}

Over the entire period considered, with the different time intervals of analysis, our study showed that the uncertainties are negligible compared to the results obtained. The overall situation is mixed since there has been a trend of shrinking of the coastline in areas where erosion is active, while in other areas accretion outweighs erosion. It should also be noted that in some places, the phenomenon is very close to stability. In general, a positive trend (fattening) has been observed in the areas of sandy spits, whereas the coastline has an erosive tendency on beaches. This situation would naturally lead to a retreat in these morpho-sedimentary units in areas with active erosion.

In short, between 1968 and 1986, the study area is characterized by an accretion over its entire extent. The reverse was observed between 1986 and 2004 with a record characterized by greater erosion. This erosion remained a determining element of the coast studied between 2004 and 2017 with, however, a lower retreat rate.

\section{References}

ABÉ J., 2005 : Contribution à la connaissance de la morphologie et de la dynamique sédimentaire du littoral ivoirien (cas du littoral d'Abidjan). Essai de modélisation en vue d'une gestion rationnelle -STRM, Université de Cocody, 197p.

BAKHOUM P.W., NDOUR A., NIANG I., SAMBOU B., TRAORE V. B., DIAW A. T., SAMBOU H., NDIAYE M. L., 2017: Coastline Mobility of Goree Island (Senegal), from 1942 to 2011. Marine Science 2017, 7(1): 1-9 DOI: 10.5923/j.ms.20170701.01.

BIRD E.C.F., 1985: Coastline changes. A global review. John Wiley \& Sons, Chichester, New York, Brisbane, Toronto, Singapore, 219 p.

BOAK, E.H., TURNER, I.L., 2005: Shoreline Definition and Detection: A Review. Journal of Coastal Research, 21(4), 688-703. West Palm Beach (Florida), ISSN 0749-0208.

BYRNES M., 1994: Shoreline position and nearshore bathymetric change, US Army Corps of Engineers. Waterways Experiment Station. VCSBURG. Report, CERC-94-9, p.61-143.

BYRNES M., LEATHERMAN S., BUCKLEY M.K., 1993: Shoreline change rate analysis: long term versus short term data. Shore and Beach, vol. 61, n², p. 13 - 20.

DADA O. A., ADEYEYE O. A., RASHEDED B.A., and YINUSA A.A. B., 2019: Effect of coastal land use change on coastline dynamics along the Nigerian transgressive Mahin mud coast. Ocean and coastal management 168, pp 251-264.

DURAND P., 2000 : Approche méthodologique pour l'analyse de l'évolution de l'évolution des littoraux sableux par photo interprétation, exemple des plages situées entre les embouchures de l'Aude et de l'Hérault (Languedoc, France), Photo interprétation, N²000/1-2, 18p. 
ESMAIL M., MAHMOD W.E., and FATHA H., 2019: Assessment and prediction of shoreline change using multi-temporal satellite images and statistics: Case study of Damietta coast, Egyp. Aplied Ocean research $n^{\circ} 82,274-282$.

FAYE I. GIRAUDET E. GOURMELON F. HENAFF A. 2013 : Cartographie normalisée du trait de côte Mappemonde. 12p.

FAYE I., 2010 : Dynamique du trait de côte sur les littoraux sableux de la Mauritanie à la Guinée-Bissau (Afrique de l'ouest) : approche régionale et locale par photo-interprétation, traitement d'images et analyses de cartes anciennes, Thèse de l'université de Bretagne occidentale, $321 \mathrm{p}$.

FEDERICO I.I., CORTIZO L., MERLOTTO A., BÉRTOLA G., MELISA P.A, 2018 : Cecilia Finocchietti, and Erosion in Buenos Aires province: Coastal-management policy revisited, Ocean \& Coastal Management, Volume 156, Pages 107-116, ISSN 09645691,https://doi.org/10.1016/j.ocecoaman.2017.09.008.

FLETCHER C.H., ROONEY J.J., BARBEE M., LIM S.C., RICHMOND B., 2003: Mapping shoreline change using digital orthophotogrammetry on Maui, Hawaii. Journal of Coastal Research, Special Issue n³8, pp 106 - 124.

GIBBS, A.E., OHMAN, K.A., AND RICHMOND, B.M., 2015: National assessment of shoreline change -- A GIS compilation of vector shorelines and associated shoreline change data for the north coast of Alaska, U.S.-Canadian border to Icy Cape: U.S. Geological Survey Open-File Report 2015-1030.

GOULD A I., KINSMAN N.E.M., HENDRICKS M.D., 2015: Guide to Projected Shoreline Positions in the Alaska Shoreline Change Tool, (http://dx.doi.org/10.14509/shoreline), Department of natural resources, Division of Geological \& Geophysical Surveys

HIMMELSTOSS, E.A., 2009: "DSAS 4.0 Installation Instructions and User Guide” in: Thieler, E.R., Himmelstoss, E.A.,Zichichi, J.L., and Ergul, Ayhan. 2009 Digital Shoreline Analysis System (DSAS) version 4.0 An ArcGIS extension for calculating shoreline change: U.S. Geological Survey Open-File Report 2008-1278. Updated for version 4.3.

LE BERRE I., HENAFF A., DEVOGELE T., MASCRET A., WENZEL F., 2016 : «SPOT5: un outil pertinent pour le suivi du trait de côte ? », Norois [En ligne], 196 |2005/3, mis en ligne le 15 décembre 2008, consulté le 30 septembre 2016. URL: http://norois.revues.org/378; DOI: 10.4000/norois.378.

MAANAN M., MAANAN M., RUEFF H, ADOUK N., ZOURARAH B and RHINANE H., 2018: Assess the human and environmental vulnerability for coastal hazard by using a multicriteria decision analysis. Human and Ecological Risk Assessment: An International Journal, DOI: 10.1080/10807039.2017.1421452.

MARTÍNEZ C., LÓPEZ M C., WINCKLER P., HIDALGO H., GODOY E., AGREDANO R., 2018: Coastal erosion in central Chile: A new hazard?, Ocean \& Coastal Management, Volume156,Pages 141-155,ISSN0964-5691,https://doi.org/10.1016/j.ocecoaman.2017.07.011. (http://www.sciencedirect.com/science/article/pii/S0964569117301564).

MOORE L. J., 2000: Shoreline mapping techniques. Journal of Coastal Research, vol. 16, $\mathrm{n}^{\circ} 1$, p. $111-124$.

MOUSSAID J., FORA A. A., ZOURARAH B., MAANAN M and MAANAN M., 2015: Using automatic computation to analyze the rate of shoreline change on the Kenitra coast, Morocco. Ocean Engineering n ${ }^{\circ} 102$ 71-77. 
MRINI A. E., MAANAN M., ANTHONY E.J., TAAOUATI M., 2012: An integrated approach to characterize the interaction between coastal morphodynamics, geomorphological setting and human interventions on the Mediterranean beaches of northwestern Morocco. Applied Geography n³5, 334-344.

NASSAR K., MAHMOD W.E., FATHA H., MASRIA A., NADAOKA K., NEGM A., 2018: Shoreline change detection using DSAS technique: Case of North Sinai coast, Egypt. Marine Georesources \& Geotechnology, DOI: 10.1080/1064119X.2018.1448912.

NDOUR A., LAÏBI R A., SADIO M., DEGBE G.E., DIAW A.T., OYEDE L M., ANTHONY E.J., DUSSOUILLEZ P., SAMBOU H., DIEYE E.B., 2018: Management strategies for coastal erosion problems in West Africa: Analysis, issues, and constraints drawn from the examples of Senegal and Benin. Ocean \& Coastal Management 156, pages 92-106.

PASKOFF R., 2001 : L'élévation du niveau de la mer et les espaces côtiers, le mythe et la réalité. Paris, Institut Océanographique, 92p.

PENNOBER G., 1999. Analyse spatiale de l'environnement Côtier de l'Archipel des Bijagos (Guinée Bissau), Thèse de Doctorat, Université de Bretagne Occidentale, 232 p.

ROBIN M., GOURMELON F., 2016 : La télédétection et les SIG dans les espaces côtiers. Eléments de synthèse à travers le parcours de François Cuq, Norois [En ligne], 196 | 2005/3, mis en ligne le 15 décembre 2008, consulté le 12 août 2016. URL : http://norois.revues.org/368 ; DOI : 10.4000/norois.368.

ROQUES C., BENGOUBOU V. M., LE COZANET G., 2010 : Evolution et dynamique du trait de côte de l'archipel Guadeloupéen. Etude de 1956 à 2004. BRGM/RP-58750-FR, 93pages, 28 illustrations, 5 annexes

SADIO M., 2017 : Morphodynamique et aménagement des flèches littorales de la côte du Sénégal, Thèse de doctorat, UCAD ; AIX Marseille Université, 375p.

STEFAN M., ANTON M., CHARLES G., 2017: Application of the Coastal Hazard Wheel to assess erosion on the Maltese coast, Institute of Earth Systems, University of Malta, Msida MSD 2080, Malta Ocean \& Coastal Management 156p (2018) 209e222.

SY A. A., 2013 : Dynamique sédimentaire et risques actuels dans l'axe Saint-Louis-Gandiol, littoral Nord du Sénégal, Thèse de Doctorat, UGB, 328 p.

TAHRI M., MAANAN M., MAANAN M., BOUKSIM H., HAKDAOUI, M., 2017: Using Fuzzy Analytic Hierarchy Process multi-criteria and automatic computation to analyse coastal vulnerability. Physical Geography, Vol. 41(3) 268-285.

THIOR M., SANE T., SY O., DESCROIX L., BA B D., SOLLY B., MENDY V., 2019a : Analyse Spatiale de l'évolution du trait de côte autour de l'embouchure du Fleuve Casamance (Sénégal) de 1968 à 2017, à Partir de l'outil DSAS, European Scientific Journal March 2019 editionVol.15,No.9,Doi:10.19044/esj.2019.v15n9p106

THIOR M., SANE T., SY O., DESCROIX L., G NDIAYE L., SOLLY B., CISSOKHO D., SAMBOU A .K 2019b : Caractéristiques granulométriques et dynamique sédimentaire entre les différentes unités géomorphologiques du littoral de la Casamance (Sénégal), », Revue Ivoirienne des Sciences et Technologie., 33 (2019) 22p. 